\title{
Regulation and Contract Choice in the Distribution of Wine*
}

\author{
Michelle Santiago $^{a}$ and Michael Sykuta ${ }^{b}$
}

\begin{abstract}
The wine industry in the United States has grown tremendously over the past few decades, from fewer than 1,000 wineries in 1980 to upward of 8,500 today. The growth has occurred over a period that has seen substantial changes in the structure of the wine industry, the modes of distribution available to wineries, and the regulations governing them. Most economic research, however, has focused on supply relations between wineries and wine grape growers rather than between wineries and their downstream markets. In this article, we examine wineries' contracting behavior with downstream distributors and the effects of industry structure, winery organizational structure, and state laws regarding direct shipment and distribution franchise laws. (JEL Classifications: D23, L14, L22, L66)
\end{abstract}

Keywords: wine distribution, regulation, franchise laws, direct shipment.

\section{Introduction}

The wine industry in the United States has grown tremendously over the past few decades, from fewer than 1,000 domestic wineries in 1980 to upward of 8,500 today. ${ }^{1}$ Wine consumption has also increased, both in total gallons (from 480 to 893 million) and per capita (from roughly 2.1 to 2.8 gallons). ${ }^{2}$ At the same time, the number of wine distributors in the United States has declined dramatically,

\footnotetext{
* The authors thank Jason Franken, Peter Klein, Laura McCann, and two anonymous reviewers for helpful comments. They also gratefully acknowledge support from the Contracting and Organizations Research Institute at the University of Missouri. This material is based upon work that was also supported by the National Institute of Food and Agriculture, U.S. Department of Agriculture, Hatch Project 218445. ${ }^{a}$ Hutson School of Agriculture, 215 Oakley Applied Science South, Murray State University, Murray, KY 42071; e-mail: msantiago1@murraystate.edu.

${ }^{\mathrm{b}}$ Division of Applied Social Sciences and Contracting and Organizations Research Institute, 135B Mumford Hall, University of Missouri-Columbia, Columbia, MO 65211-6200; e-mail: sykutam@missouri.edu (corresponding author).

${ }^{1}$ Wines \& Vines winery database reports there were 8,543 bonded wineries in the United States in September 2015 (http://winesandvines.com; accessed October 20, 2015).

2 "Wine Consumption in the U.S.," Wine Institute, (http://www.wineinstitute.org/resources/statistics/ article86; accessed November 1, 2015).
} 
dropping from 7,000 in 1995 to fewer than 770 by 2008 (Insel, 2008). This decline in distributors is significant not only for its magnitude, but also because distributors play a key role in states' traditional three-tier regulatory structures for all alcohol distribution, including wines. Moreover, several states maintain distribution franchise laws that grant distributors effective leverage in their relations with wine suppliers. Both the concentration of distributors and the existence of distribution franchise laws create potential contracting hazards for wineries seeking to grow their business through the traditional three-tier system.

An alternative to the three-tier system for distributing wine, particularly for small and medium-size wineries, has been the expansion of interstate shipment of wine directly to consumers. Beginning in 1986, a growing number of states adopted laws allowing wineries in other states to ship wine directly to consumers in their states (Riekhof and Sykuta, 2005). In 2005, the U.S. Supreme Court further opened the door for direct interstate shipments in Granholm v. Heald, ruling that states cannot discriminate between in-state and out-of-state wineries in allowing direct shipment to states' consumers. Since then, many states have amended their direct shipment laws to allow shipment from any state, but typically with some form of permitting. Presently, only eight states continue to prohibit direct shipment to consumers. ${ }^{3}$ The expansion of direct shipment provides an opportunity for small and medium-size wineries, in particular, to expand their market access while circumventing the increasingly concentrated and heavily regulated wholesale distribution system.

Despite the growing importance of the wine industry in the U.S. agricultural economy, the value chain in wine is not well studied. Most economic research has focused on supply relations between wineries and wine grape growers (FernándezOlmos, Rosell-Martínez, and Espitia-Escuer, 2009; Franken, 2014; Franken and Bacon, 2014; Goodhue et al., 2003; Zylbersztajn and Miele, 2005) or on consumerlevel supply and demand characteristics (for a broad survey, see Storchmann, 2012). There is little research on the structure of the value chain between the winery and the retailers from whom the wine is ultimately purchased. Sun et al. (2014) examine the choice of distribution channel for wineries in emerging cool wine-producing regions, but not directly how those relationships are structured nor the effects of different state regulatory structures on those relationships.

In this article, we examine wineries' transaction relationships with downstream distributors and the effects of state laws regarding direct shipment and distribution franchise laws on the choice of transaction governance. Using primary data from a survey of wine producers, we examine the use of formal, written contracts between wineries and their distributors and how the nature of state-level regulations on distribution and distributor relations affects contract choice and design.

\footnotetext{
${ }^{3}$ Information on current state direct shipping laws is available from the Wine Institute (http://www. wineinstitute.org).
} 


\section{Distribution in the Wine Industry}

Since the repeal of Prohibition with the Twenty-First Amendment, regulation of alcohol distribution has been primarily governed at the state level. Almost uniformly, states adopted a three-tier regulatory structure requiring producers of alcoholic beverages to sell their products to state-licensed or franchised wholesalers who then distribute the products to licensed retailers for resale to end consumers. Exceptions were made in most states for (particularly small) producers to sell their products directly to consumers, but only on premises and often requiring food service as well, thereby limiting direct retail possibilities.

An effect of the three-tier system is to increase the costs of distributing wine, particularly for small wineries (Thornton, 2013). Because distributors must be licensed within each individual state and states typically grant geographic monopolies to distributors of specific brands, there are no national distributors and relatively few multistate distributors. Consequently, wineries must develop relationships with many distributors if they hope to sell their product at the regional or national level. Moreover, because retail is a volume-driven business, distributors have incentives to carry and promote labels that sell in large volumes. This places small and even midsize wineries at still greater disadvantage. ${ }^{4}$

Exacerbating this problem is the change in industry structure at the winery and distributor levels. As noted previously, the number of domestic wineries in the United States has increased dramatically in the past 30 years, whereas the number of distributors has decreased by nearly $90 \%$. This creates a bottleneck for smaller producers seeking to access the retail market and gives distributors not only greater bargaining power ex ante, but also greater ability to engage in ex post opportunism as well.

This asymmetry of relational power between wineries and distributors (both ex ante and ex post) is further exacerbated in some states due to distribution franchising laws that collectively provide protection to the state's distributors, either through territory or termination provisions (or both). ${ }^{5}$ Territory provisions grant the distributor a territorial monopoly over distribution of a wine brand from the time the distributor first carries the label. Termination provisions specify conditions under which producers can terminate their relationship with a distributor and typically require either (1) written notice at least 60 days in advance - which may threaten the producer's ability to move product in the interim - or (2) termination only on the basis of "good cause," which can be difficult to prove in court. Distributors, on the other hand,

\footnotetext{
${ }^{4}$ Thach and Olsen (2006) found that the top factors affecting distributors' decision to carry a wine in its portfolio are the taste of wine, the dependability of the supplier, the price of the wine, the personal relationship the distributor has with the winery, customer service received from the winery, and the wine label. ${ }^{5}$ These distribution franchise laws are different than the laws governing traditional business platform franchise agreements.
} 
do not have substantial exit barriers to the distribution relationship. Distributors may formally terminate the agreement by notice or de facto terminate the agreement by simply not reordering a supplier's product. As a result, franchise distribution laws may create a lock-in situation for wineries.

Anecdotal evidence from trade publications and conversations with distributors and winery owners suggests that distribution agreements between wineries and wholesale distributors have traditionally been informal, oral agreements couched in this highly regulated institutional environment. Furthermore, contract terms grant most significant decision rights-including marketing, product promotion, and termination - to the distributor. Thach and Olsen (2006, p. 75) claim that because "distributors maintain a position of power over most wineries," the two parties traditionally have not had a mutual incentive to build a relationship that equally benefits both parties.

In some cases, wineries may choose to circumvent distributors by vertically integrating forward and acquiring a wholesaler license to distribute their own products to licensed retail sellers and servers. However, such distribution networks tend to be smaller scale and limited to local or regional markets in which winery owners have personal relationships with local restaurateurs and retailers.

Direct shipment provides wineries an alternate distribution mechanism to reach off-premises consumers without going through a wholesale distributor (Riekhof and Sykuta, 2005). In 2014, direct-to-consumer shipments from domestic wineries totaled more than $\$ 1.8$ billion and constituted approximately $18 \%$ of all off-premises wine sales. ${ }^{6}$ Wineries in states that allow direct shipment may be less dependent on the traditional three-tier system. This relative independence would seem to be of even greater value in states with franchise distribution laws. Given these market alternatives, one might expect that the nature of contractual relations between wineries and wholesale distributors would be different for wineries that have such additional market opportunities.

\section{Contracting and Contract Design}

Every transaction fundamentally entails an allocation of value, an allocation of uncertainty, and an allocation of decision rights (Sykuta, 2012). These allocations are determined by the structure of decision rights, incentives, and performance measures specified (or implied) in the organizational form governing the transaction, whether simple market trades, contracts, or hierarchical structures. Consequently, the array of potential factors affecting the use and structure of contracts is as potentially

\footnotetext{
${ }^{6}$ Wines \& Vines (see footnote 1) lists off premises and direct to consumer as two different distribution channels. For our purposes, we combine the two as distinct from on-premises sales through tasting rooms, winery storefronts, and on-premises restaurant sales.
} 
broad as the factors affecting the nature of the value created, the sources of uncertainty, and the nature of decisions inherent to the performance of the deal.

Economic research on contracts generally appeals either to agency theory or transaction cost economics (TCE). Although agency theory has been productively applied to issues of contracting in financial and human capital markets (Jensen and Meckling, 1976; Kahan and Yermack, 1998), Masten and Saussier (2002) argue that agency theory offers little to explain the decision to contract, contractual completeness, or the design of many contract terms, instead focusing primarily on incentive alignment and risk sharing.

A hallmark of Williamson's $(1979,1985)$ TCE is the concept of asset specificity and the potential for opportunistic holdup among transacting parties. Although it is difficult to argue that a winery's assets are in some sense specific to a particular distribution agreement - and even more so for the distributor's assets - the nature of alcohol regulation does create a level of dependence among transacting parties that would have similar economic incentive effects, especially where smaller and medium-size wineries are concerned. Particularly in states with distribution franchising laws, the relationship between a winery and distributor undergoes what Williamson (1979) refers to as a "fundamental transformation," perhaps not creating a true bilateral monopoly, but nonetheless making the winery's label - and its potential market value - specific to (and dependent on) the distributor in that geographic market. In this sense, the nature of the regulatory environment itself creates a type of asset specificity.

TCE suggests that as the degree of potential holdup increases, firms will move along the continuum of governance structures, from market to hybrid to hierarchy. Contracting is typically considered a form of hybrid, including elements of market transactions (dyadic relationships) with elements of hierarchical control in the ways in which decision rights are structured. As contracts increase in formality, completeness, and duration, the governance system becomes more hierarchical in nature. Thus, we would expect wineries in states with greater dependence on distributors to have more formal distribution agreements. Because state distribution franchise laws and prohibitions on direct-to-consumer shipping increase dependence on distributors to reach off-premises consumers, we would expect wineries in states with such regulations to use more formal distribution agreements to protect against opportunistic behavior by the distributor.

Contract formality is often discussed in the context of relational contracting (Macaulay, 1963). There is no unified definition of relational contracting. It has been interpreted as an incomplete contract that only accounts for general terms and relationship goals while specifying some decision-making methods (Milgrom and Roberts, 1992), a long-term incomplete contract in which prior relationships and dealings matter (Furubotn and Richter, 1998), and an implicit (i.e., not formal) contract that directs both parties' behaviors (Baker et al., 2002). In general, however, relational contracting focuses not just on the governance mechanism itself, 
but also on the relationship between trading parties (Poppo and Zenger, 2002; Poppo and Zhou, 2014). In this context, trust plays an important role in contract design (Crocker and Reynolds, 1993; Williamson, 1996). We therefore expect wineries that have had previous legal disputes to be more likely to use written distribution agreements.

Closely related is the concept of contractual completeness. Although contractual completeness is often described in terms of whether the contract provides direction under all possible contingencies, Scott (2006) argues there are two dimensions of completeness: obligational and informational. Obligational completeness is the idea that the contract specifies parties' obligations under all possible contingencies. However, the obligations specified in the contract may turn out not to be efficient ex post because they do not take into account new information (i.e., they are not informationally complete). Such informational incompleteness could give rise to what Williamson (1996) refers to as "maladaptation costs," as parties take advantage of contract terms that may be ex post inefficient. So even though a contract may be complete in an obligational sense, it may not be informationally complete or informationally efficient.

The efficient level of completeness balances the ex ante costs of negotiating more complete contracts and the expected ex post costs of disputes arising from incomplete contracts (Crocker and Reynolds, 1993; Scott, 2006). The greater the ex post uncertainty, the higher the costs of negotiating ex ante and the less complete the contract. The greater the potential harm or cost of ex post disputes, the more complete the contract.

In the case of wine distribution agreements, the effects of regulation on completeness are somewhat ambiguous. Although distribution franchise laws may increase the perceived value of having a written agreement specifying performance expectations, the laws' provisions for termination may substitute for negotiated termination clauses. Although the ability to ship directly to consumers may make wineries less reliant on distributors, it may provide wineries the opportunity to negotiate additional protections, or distributors an incentive to contractually limit the wineries directto-consumer distributions in the distributor's territory.

The complexity of contracts may reflect the level of completeness of the deal to account for a complex set of contingencies. For our study, we are concerned with a slightly different understanding of complexity - namely, the complexity of the contracting environment. In the wine industry, distribution agreements generally focus on product mix, product volume, pricing, and possibly some mutual expectations of the distributor's responsibilities. Some wineries go further in having performance and/or marketing agreements that set specific performance targets or responsibilities specifically around marketing activities in addition to their basic distribution agreements. These agreements do more to align the incentives of the distributor and winery than does the simple distribution agreement. Like completeness, we expect the complexity of contracts to increase with the expected (net) benefits of including 
additional performance and marketing standards. Consequently, as with completeness, we have no a priori hypothesis about the effects of distribution regulations on the complexity of the contracting mechanisms used.

\section{Data and Model}

We used data from a 2008 survey of winery owners or managers regarding their distribution practices and perceptions of the potential effect of changes in interstate direct shipment regulations. Following Dillman (2000), a stratified sample of 2,225 wineries was randomly selected from a population of approximately 4,500 wineries listed in the 2007 edition of Wines \& Vines Directory \& Buyer's Guide. The guide included contact information for the winery owner or executive, as well as other winery characteristics. The survey asked a series of questions about the winery's size and product mix, market channels, distribution channels, and the types of distribution, marketing, and performance contracts used by the winery. Respondents were also asked their expectations about changes in future contracting practices given changes in direct shipment laws at the time. ${ }^{7}$ After one postcard reminder and one e-mail reminder, 151 usable responses were collected. Response data were supplemented by information contained in the Wines \& Vines Buyer's Guide.

Despite the relatively low response rate, the usable sample is larger than is often available for contracts research, particularly in the wine industry. ${ }^{8}$ Franken and Bacon (2014) use a sample of 25 survey responses supplemented with U.S. Department of Agriculture data on 71 additional observations. Franken (2014) uses a sample of 105 grape procurement contracts. Table 1 includes a summary of the solicited sample and response set by state. The respondent sample has a slightly higher proportion of wineries from states that prohibit direct shipment than the survey sample. Aside from geography, the distribution of wineries is reasonably reflective of the U.S. wine industry, as shown in Table 2. Wines \& Vines reports that $77 \%$ of wineries produced fewer than 5,000 cases per year, and $18 \%$ produced between 5,000 and 49,999 in 2012. In our sample, wineries in those size categories comprise $64 \%$ and $31 \%$ of our sample, respectively. However, according to Wines $\&$ Vines, half of the wineries in the smallest category are limited production wineries, producing less than 1,000 cases per year. Such wineries generally have limited distribution needs and would therefore not be likely respondents to the survey, nor would their responses shed much light on distribution relationships. If one considers commercial wine operations producing fewer than 50,000 cases per year, our sample

\footnotetext{
${ }^{7} \mathrm{~A}$ copy of the survey is available from the authors on request.

${ }^{8}$ This low response on a national survey is not too surprising given the generally proprietary and secretive nature of the industry. In describing her role as a wine economist, Insel (2008, pp. 71-72) writes, "So what is it like to be an economist in this crazy, passionate, disorganized industry? The starting point is that there are no data" (emphasis in the original).
} 
Table 1

Wine Producer Surveys Mailed and Received by State

\begin{tabular}{|c|c|c|c|c|c|c|c|c|}
\hline \multicolumn{3}{|c|}{ Direct shipment prohibited } & \multicolumn{6}{|c|}{ Direct shipment allowed } \\
\hline State & Mailed & Received & State & Mailed & Received & State & Mailed & Received \\
\hline AL & 7 & 0 & AK & 5 & 0 & MO & 63 & 7 \\
\hline AR & 6 & 0 & $\mathrm{AZ}$ & 11 & 1 & $\mathrm{NE}$ & 7 & 0 \\
\hline $\mathrm{DE}$ & 1 & 0 & $\mathrm{CA}$ & 1038 & 63 & NV & 5 & 0 \\
\hline KY & 22 & 1 & $\mathrm{CO}$ & 31 & 6 & $\mathrm{NH}$ & 6 & 2 \\
\hline ME & 8 & 0 & $\mathrm{CT}$ & 12 & 0 & NM & 13 & 2 \\
\hline MS & 2 & 0 & DC & 0 & 0 & NY & 97 & 5 \\
\hline MT & 6 & 1 & FL & 15 & 1 & $\mathrm{NC}$ & 29 & 3 \\
\hline NJ & 30 & 2 & GA & 10 & 1 & ND & 4 & 0 \\
\hline OK & 34 & 4 & HI & 4 & 1 & $\mathrm{OH}$ & 40 & 0 \\
\hline $\mathrm{PA}$ & 100 & 7 & ID & 13 & 0 & OR & 133 & 8 \\
\hline SD & 8 & 2 & IL & 32 & 2 & RI & 7 & 2 \\
\hline $\mathrm{TN}$ & 25 & 2 & IN & 17 & 3 & $\mathrm{SC}$ & 7 & 0 \\
\hline \multirow[t]{7}{*}{ UT } & 6 & 2 & IA & 21 & 1 & TX & 48 & 10 \\
\hline & & & $\mathrm{KS}$ & 10 & 1 & VT & 8 & 0 \\
\hline & & & LA & 7 & 1 & VA & 51 & 5 \\
\hline & & & MD & 10 & 1 & WA & 172 & 19 \\
\hline & & & MA & 7 & 1 & WV & 7 & 0 \\
\hline & & & MI & 35 & 0 & WI & 14 & 1 \\
\hline & & & $\mathrm{MN}$ & 8 & 1 & WY & 2 & 1 \\
\hline Total & 255 & 21 & Total & & & & 2,000 & 149 \\
\hline
\end{tabular}

Notes: This table shows the breakdown of producer surveys mailed and received, by direct shipment policy and by state. A stratified sampling technique was used to narrow the total winery population from $4,000+$ to 2,255 . Missouri was the only exception to this proportional sampling in direct shipment states, as all wine producers in the state were sent a survey.

Table 2

Distribution of Wineries by Size, Sample versus U.S. Wine Industry

\begin{tabular}{lcc}
\hline Annual case production & Respondent sample & U.S. wine industry, 2012 \\
\hline Less than 5,000 & $63.6 \%$ & $77 \%$ \\
$5,000-49,999$ & $31.1 \%$ & $18 \%$ \\
$50,000-499,999$ & $3.2 \%$ & $3 \%$ \\
More than 500,000 & $1.9 \%$ & $1 \%$ \\
\hline
\end{tabular}

Note: U.S. wine industry distribution by sales according to Wines \& Vines winery database report for February 2012 (http://winesandvines. com; accessed October 20, 2015).

seems reasonably representative of the industry. Table 3 provides a description of our variables and summary statistics.

As is typical in contracts research (Sykuta, 2008), the dependent variables of interest are discrete binary, multinomial, ordinal, or count-type data representing the choice of formal versus informal contracts, the choice of organizational form, the complexity of contracting structures, and the (obligational) completeness of 
Table 3

Variable Descriptions and Summary Statistics

\begin{tabular}{|c|c|c|c|c|c|}
\hline Variable & Observations & Mean & $\begin{array}{l}\text { Standard } \\
\text { deviation }\end{array}$ & Minimum & Maximum \\
\hline \multicolumn{6}{|l|}{ Contract variables } \\
\hline $\begin{array}{l}\text { Written distribution agreement } \\
\text { (WDA) }(=1 / 0)\end{array}$ & 105 & 0.447 & 0.499 & 0 & 1 \\
\hline WDA complete & 46 & 4.326 & 2.098 & 1 & 10 \\
\hline WDA duration (categorical) & 105 & 3.314 & 1.266 & 0 & 4 \\
\hline Contracting complexity & 107 & 1.617 & 1.371 & 0 & 5 \\
\hline Performance agreement $(=1 / 0)$ & 95 & 0.421 & 0.496 & 0 & 1 \\
\hline Marketing agreement (=1/0) & 99 & 0.606 & 0.491 & 0 & 1 \\
\hline \multicolumn{6}{|l|}{ Winery variables } \\
\hline Age of winery & 149 & 13.751 & 15.339 & 2 & 125 \\
\hline Annual sales (categorical) & 151 & 2.146 & 2.249 & 1 & 17 \\
\hline $\begin{array}{l}\text { Multiple distribution channels } \\
(=1,2,3)\end{array}$ & 144 & 2.479 & 0.689 & 1 & 3 \\
\hline $\begin{array}{l}\text { Home state allows direct ship- } \\
\text { ment }(=1 / 0)\end{array}$ & 166 & 0.873 & 0.333 & 0 & 1 \\
\hline $\begin{array}{l}\text { Distributes to a direct shipment } \\
\text { state }(=1 / 0)\end{array}$ & 131 & 0.710 & 0.455 & 0 & 1 \\
\hline Number of states distributed to & 131 & 9.198 & 13.100 & 0 & 51 \\
\hline $\begin{array}{l}\text { Had previous legal dispute with } \\
\text { distributor }(=1 / 0)\end{array}$ & 118 & 0.102 & 0.314 & 0 & 1 \\
\hline \multicolumn{6}{|l|}{ Market characteristic variables } \\
\hline $\begin{array}{l}\text { State wine market size (thousand } \\
\text { gallons) }\end{array}$ & 166 & 58,579 & 54,152 & 767 & 127,285 \\
\hline Distributor HHI & 166 & 1,912 & 1,350 & 0 & 8,546 \\
\hline
\end{tabular}

HHI = Herfindahl-Hirschman Index

contracts. At its simplest, each model is of the following form:

$$
\operatorname{prob}(Y)=\alpha+\beta W+\gamma Z+\delta M+\varepsilon
$$

where $Y$ is the dependent variable of interest, $W$ is a set of winery-specific control variables, $M$ is a set of regional market characteristics, and $Z$ is a set of treatment variables reflecting the regulatory context. This simple model is estimated using logistic, ordered logit, or Poisson regression techniques as is appropriate to the dependent variable of interest.

\section{Results}

\section{A. Regulation and Contract Formality}

Our primary interest is how regulations on the distribution of wine affect the formality of wine distribution agreements. As discussed previously, our hypothesis is that wineries will be more likely to have formal, written distribution agreements when 
the potential for distributor opportunism is higher. This suggests that wineries in states with franchise laws and wineries in states that limit direct shipment to consumers will be more likely to have written agreements, as these regulations grant greater decision rights to distributors and limit wineries' alternative channels of distribution. We also include a measure of distributor concentration in the winery's home state as an additional control for structural constraints on the winery's distribution opportunities.

In addition to the regulatory variables, we expect certain winery characteristics to affect the use of written agreements. First, the size and age of the winery are expected to be positively associated with the use of formal contracts. Larger firms are likely to have larger valued contracts, making the transaction costs of negotiating formal agreements more worthwhile (Anderson and Dekker, 2005). We also expect older wineries to be more likely to have more formal - and more detailed - contracting relationships. Ryall and Sampson (2009) find that repeated transactions - whether with the same or different partners-lead firms to develop more formal and more complete contracts. Older firms that have repeated experience with distributors are therefore expected to have formal agreements.

Wineries with a broader portfolio of products and wineries distributing to more states would incur higher costs for negotiation of written distribution agreements with several different distributors over several different products, thereby decreasing the likelihood of written agreements. Wineries using multiple distribution channels (direct to consumer, direct to retail, or through third-party distributors) are less reliant on any one channel and therefore may be less likely to engage in formal distribution contracts. Wineries that have had previous legal disputes with distributors are more likely to have written agreements. Finally, we include variables reflecting the size of the state's wine market as a proxy for potential benefits of distribution and as a measure of sales uncertainty.

The results of a binary logistic regression model are reported in Table 4 and include both the estimated coefficients and the marginal effects. As expected, state laws regulating wine distribution have statistically significant effects on the use of formal contracts. Franchise laws increase the likelihood of formal, written distribution agreements by $22 \%$, whereas laws allowing direct shipment reduce the likelihood of written agreements by $36 \%$. This is consistent with the primary hypothesis concerning the effects of wine distribution regulations. Similarly, previous legal disputes with distributors increase the use of written distribution agreements. The size and age of the winery are positively related to the use of distribution agreements, as expected. This is also consistent with Franken and Bacon's (2014) results, which show that larger and older wineries are more likely to sell through distributors. Wineries with larger product portfolios and that sell to more states (suggesting a larger number of distributors) are less likely to have written distribution agreements. Wineries in states with larger markets and with more heavily concentrated distribution industries are also more likely to use written contracts. 
Table 4

Distribution Contract Formality Model Results

\begin{tabular}{lccc}
\hline Variable name & Coefficient & Marginal effect & Robust standard error \\
\hline Constant & -2.3843 & & 1.6221 \\
Years in existence & 0.0163 & 0.0040 & 0.0140 \\
Annual sales & 0.3276 & 0.0799 & $0.1875^{*}$ \\
Products produced & -0.9587 & -0.2339 & $0.4917^{* *}$ \\
Retail markets & 0.6366 & 0.1553 & 0.4532 \\
Legal dissatisfaction (=1) & 1.9774 & 0.4410 & $1.0324^{*}$ \\
Number of states winery distributes & -0.0859 & -0.0210 & $0.0347^{* * *}$ \\
Size of state wine market & $1.92 \mathrm{e}-05$ & $4.69 \mathrm{e}-06$ & $8.6 \mathrm{e}-06^{* *}$ \\
State direct shipment law (=1) & -2.2147 & -0.4782 & $1.1744^{* *}$ \\
Distribution franchise law (=1) & 1.2443 & 0.2719 & $0.7451^{* *}$ \\
Distributor concentration (HHI) & 0.0007 & 0.0002 & $0.0003^{* *}$ \\
Number of observations & & 82 & \\
Log likelihood & & -45.068 & \\
Wald $\chi^{2}(10)$ & & 18.69 & \\
Probability $>\chi^{2}$ & & 0.0443 & \\
Pseudo $R^{2}$ & & 0.1985 & \\
\hline
\end{tabular}

Notes: This table presents results of a binary logistic regression of the likelihood of a formal agreement occurring. The regressions are based on a sample of 82 survey respondents. Legal dissatisfaction is a dummy variable equal to 1 if the winery ever legally documented dissatisfaction with a distributor. State direct shipment law is set to 1 if the state allows direct shipment of wine. Likewise, the state franchise law is set to 1 if the winery distributes to a state with franchise distribution laws. The model is estimated with robust standard errors. The asterisks $(* * *, * *$, and $*$ ) signify statistical significance at the $1 \%, 5 \%$, and $10 \%$ levels, respectively. HHI $=$ Herfindahl-Hirschman Index.

\section{B. Completeness of Distribution Agreements}

As noted previously, contract completeness involves not only specifying parties' obligations for every possible contingency (i.e., obligational completeness), but also specifying obligations that are economically efficient given ex post information revelation (i.e., informational completeness). These two dimensions of completeness tend to be held in tension, as flexibility to respond to new information often comes at the expense of ex ante obligational completeness. For this study, we identify a set of potential contract terms that tend to be used in wine distribution agreements based on trade publications and conversations with industry participants. Seven terms focus on quantity and quality standards, order approvals, and incentives, and five focus on dispute resolution and termination conditions. Although certainly not exhaustive, these terms represent both obligational and some informational clauses. Our measure of completeness is simply the number of the 12 identified clauses included in the winery's distribution contracts.

Given the count nature of our completeness variable, we perform a Poisson regression of completeness on a set of winery, market, and regulatory variables. We expect the winery's size to be positively related to completeness due to the increased value at risk, as discussed previously for contract formality. We also expect age to be positively related to completeness, whether due to learning between partners (Mayer and Argyres, 2004) or simply from repeated experience (Ryall and Sampson, 2009). 
Table 5

Contract Completeness of Wine Distribution Agreements

\begin{tabular}{|c|c|c|c|}
\hline Variable name & Coefficient & Marginal effect & Robust standard error \\
\hline Years in existence & -0.0017 & -0.0065 & 0.0017 \\
\hline Annual sales & 0.0433 & 0.1689 & $0.0111 * * *$ \\
\hline Distribution channels & -0.0369 & -0.1439 & 0.940 \\
\hline Distribution contract duration & -0.0512 & -0.1994 & 0.0550 \\
\hline State direct shipment law $(=1)$ & 0.3738 & 1.2931 & $0.1954 * *$ \\
\hline Distribution franchise law $(=1)$ & -0.4911 & -2.2843 & $0.1578 * * *$ \\
\hline Distributor concentration (HHI) & -0.0033 & -0.0013 & $0.0001 * * *$ \\
\hline Size of wine market & $1.82 \mathrm{e}-07$ & $7.10 \mathrm{e}-07$ & $1.82 \mathrm{e}-06$ \\
\hline Marketing agreement (=1) & -0.0352 & -0.1380 & 0.1672 \\
\hline Performance agreement $(=1)$ & -0.0525 & -0.2054 & 0.1491 \\
\hline Constant & 2.1450 & & $0.2944 * * *$ \\
\hline Number of observations & \multicolumn{3}{|c|}{29} \\
\hline Log likelihood & \multicolumn{3}{|c|}{-52.551} \\
\hline Wald $\chi^{2}(10)$ & \multicolumn{3}{|c|}{62.98} \\
\hline Probability $>\chi^{2}$ & \multicolumn{3}{|c|}{0.0000} \\
\hline Pseudo $R^{2}$ & \multicolumn{3}{|c|}{0.1283} \\
\hline Deviance goodness of fit $=15.2166$ & \multicolumn{3}{|c|}{ Probability $>\chi^{2}(18)=0.6470$} \\
\hline Pearson goodness of fit $=13.9756$ & & \multicolumn{2}{|c|}{ Probability $>\chi^{2}(18)=0.7307$} \\
\hline
\end{tabular}

Notes: This table presents results of a Poisson regression of the completeness of distribution agreements. The regressions are based on a sample of 29 survey respondents. State direct shipment law is set to 1 if the state allows direct shipment of wine. Likewise, the state franchise law is set to 1 if the winery distributes to a state with franchise distribution laws. The model is estimated with robust standard errors. Asterisks $(* * * * *$, and $*)$ signify statistical significance at the $1 \%, 5 \%$, and $10 \%$ levels, respectively. HHI $=$ Herfindahl-Hirschman Index.

We expect wineries with multiple distribution channels to have less complete distribution contracts because the winery is less reliant on any one distribution channel. We include duration of the distribution agreement and the use of performance and marketing agreements. We would expect a negative relation between completeness and duration because longer-term agreements are subject to greater uncertainty and possible information incompleteness (Scott, 2006). We also expect a negative relation between completeness in the distribution agreement and the use of supplemental agreements that may substitute for terms in the distribution agreement itself. The size of the state's wine market and the degree of distributor concentration control for differences in market structure. Finally, we include our regulatory variables to determine whether the regulatory environment affects contract design.

Table 5 presents the results of the Poisson contract completeness model along with the marginal effects. Deviance goodness-of-fit and Pearson goodness-of-fit tests fail to reject the null hypothesis that the data are Poisson distributed. ${ }^{9}$ The effects of our regulation variables are both significant and appear to work in opposite directions. In states that allow direct shipment, distribution agreements have 1.3 more clauses than in nonshipment states. When wineries distribute to franchise law states, distribution

\footnotetext{
${ }^{9}$ The deviance and Pearson $\chi^{2}$ test statistics for goodness of fit had $P$ values of 0.65 and 0.73 .
} 
contracts have 2.3 fewer clauses. In addition to the regulation variables, only two other significant estimates are significant. Winery size is positively related to completeness, whereas concentration in the distribution industry is negatively related. However, although both are significant at the $1 \%$ level, the marginal effects are rather small, especially for distributor concentration.

\section{Complexity of Distribution Contracts}

Our final tests focus on the complexity of contracting in wine distribution. All wineries have distribution agreements, if only informal, relational contracts. As noted earlier, some wineries choose to use additional contracts to supplement their distribution agreements. Among those wineries using performance and/or marketing agreements, those agreements are sometimes oral agreements and sometimes formal, written contracts. We measure complexity of contracting by the mix and formality of the total contracting arrangement. Performance and marketing agreements are coded as 0 for no agreement, 1 for an oral agreement, and 2 for written contracts. The formality of distribution contracts is a binary variable equal to 1 if it is a written contract. We construct our measure of complexity by simply summing the three agreement variables, reflecting the more complex negotiations and contracting environment as additional contracts are negotiated and possibly drafted.

Because the dependent variable is not truly a count variable so much as a magnitude variable, we conduct an ordered logit regression of this complexity variable on winery age, size, product portfolio, multiple distribution channels, and number of states to which the winery distributes. As with completeness, we expect that age and size will be positively related to our complexity measure. Product portfolio may increase complexity due to a larger number of products, but this could also increase the costs of negotiating terms for the array of products, which would reduce the complexity of negotiated contractual arrangements. Similarly, we expect the number of states to which a winery distributes to be negatively related to complexity because contracts would need to be negotiated with a larger number of distributors across the different states. In addition to these winery-specific variables, we include the size of the state wine market and the concentration of distribution in the state, as well as our regulatory controls.

Table 6 shows the results of the ordered logit model. A likelihood ratio test of proportionality of odds across the response categories fails to reject the null hypothesis that there is no difference in the coefficient between models. ${ }^{10}$ Unlike our earlier results, neither of the wine distribution regulations has a significant coefficient. However, age and size do have significant, positive coefficients, as expected. Large product portfolios and distributing to more states have negative relations with

\footnotetext{
${ }^{10}$ The $\chi^{2}$ test statistic for the likelihood ratio test had a $P$ value of 0.78 , thus failing to reject the null hypothesis that the coefficients are the same across models.
} 
Table 6

Contract Complexity in Wine Distribution Agreements

\begin{tabular}{lcc}
\hline Variable name & Coefficient & Robust standard error \\
\hline Years in existence & 0.0227 & $0.0134^{*}$ \\
Annual sales & 0.4771 & $0.1670^{* * *}$ \\
Product produced & -0.7201 & $0.3459^{* *}$ \\
Multiple distribution channels & 0.1311 & 0.3482 \\
Legal dissatisfaction (=1) & 0.5947 & 0.6995 \\
Size of state wine market & 0.0001 & $6.09 \mathrm{e}-6^{*}$ \\
State direct shipment law (=1) & -0.8084 & 0.7657 \\
Distribution franchise law (=1) & 0.2902 & 0.5734 \\
Number of states distributed & -0.0554 & $0.0262^{* *}$ \\
Distributor concentration (HHI) & 0.0001 & $0.0002^{*}$ \\
Number of observations & 83 & \\
Log likelihood & -117.59 & \\
Wald $\chi^{2}(10)$ & 26.23 & \\
Probability $>\chi^{2}$ & 0.0034 & \\
Pseudo $R^{2}$ & 0.1003 & \\
Proportionality likelihood ratio & $\chi^{2}(40)=32.97$, Probability $>\chi^{2}=0.7769$ \\
\hline
\end{tabular}

Notes: This table presents results of an ordered logistic regression of the complexity of contracting arrangements. The regressions are based on a sample of 83 survey respondents. Legal dissatisfaction is a dummy variable equal to 1 if the winery ever legally documented dissatisfaction with a distributor. State direct shipment law is set to 1 if the state allows direct shipment of wine. Likewise, the state franchise law is set to 1 if the winery distributes to a state with franchise distribution laws. The model is estimated with robust standard errors. Asterisks $\left({ }^{* * *}, * *\right.$, and $*$ ) signify statistical significance at the $1 \%, 5 \%$, and $10 \%$ levels, respectively. HHI $=$ Herfindahl-Hirschman Index.

complexity, consistent with minimizing the costs of negotiating. Finally, contracting is more complex when the wine market is larger.

\section{Conclusion}

Producers of alcoholic beverages face a rather unique system of regulations to distribute their products to end consumers, with a mandatory three-tier system in most states. Given consolidation and increased concentration at the distributor level, distributors have significant ex ante bargaining power over wineries that seek to distribute through the three-tier system. State distribution franchising laws that stilt the market in favor of distributors create additional ex post hazards for wineries in their relationships with distributors. The wine industry has an additional wrinkle in the ability of producers in most - but not all — states to ship products directly to consumers, thereby circumventing the three-tier system. The unique characteristics of the alcohol distribution system and its various regulations raise questions about how the relations between wine producers and distributors are governed, which has heretofore received little attention in the literature.

Our results show that the nature of regulations in the wine industry has significant implications for the structure of distribution agreements between wineries and distributors. Distribution franchise laws that vest distributors with greater power over 
their suppliers increase the likelihood that wineries will use formal, written contracts to govern their distribution relationships. At the same time, distribution franchise laws are associated with less complete distribution contracts. Laws allowing for direct shipment seem to have a mitigating effect, reducing the likelihood of formal, written contracts, but increasing the completeness of distribution contracting arrangements.

Our results also find that firm size and age have similar effects on the formality and completeness of contracts as has been observed in previous research across a range of industries and transaction types. Likewise, our results show some evidence of economizing on contracting costs when product portfolios are larger and when wineries deal with multiple distributors across different states.

The U.S. wine industry has witnessed tremendous growth over the past three decades, and regulations at both the state and federal levels are in a dynamic state of flux. Given the growing importance of the wine industry within U.S. agriculture, it is important to understand the implications of these regulatory structures for the ways in which industry participants structure their businesses and their contractual relations. From a theoretical perspective, our results illustrate how alternative institutional structures (in this case, distribution regulations) change transaction attributes in ways that affect contract choice. More specifically, distribution laws create a form of asset specificity between wineries and their distributors that increases transaction hazards.

The results in this article suggest that there are meaningful implications of regulatory systems for the structure of distribution systems. Additional research is needed to gather more precise data from a larger number of wineries and distributors to better understand not only the structural implications, but also the implications for economic performance at the firm and industry levels.

\section{References}

Anderson, S.W., and Dekker, H.C. (2005). Management control for market transactions: The relation between transaction characteristics, incomplete contract design, and subsequent performance. Management Science, 51(12), 1734-1752.

Baker, G., Gibbons, R., Murphy, KJ. (2002). Relational Contracts and the Theory of the Firm. Quarterly Journal of Economics, 117(1): 39-84.

Crocker, K.J., and Reynolds, K.J. (1993). The efficiency of incomplete contracts: An empirical analysis of air force engine procurement. RAND Journal of Economics, 24(1), 126-146.

Dillman, D.A. (2000). Mail and Internet Surveys: The Tailored Design Method, 2nd ed. New York: John Wiley and Sons.

Fernández-Olmos, M., Rosell-Martínez, J., and Espitia-Escuer, M.A. (2009). Vertical integration in the wine industry: A transaction costs analysis on the Rioja DOCa. Agribusiness: An International Journal, 25(2), 231-250.

Franken, J.R.V. (2014). Coordination of the California winegrape supply chain. Journal of Wine Economics, 9(2), 183-201. 
Franken, J.R.V., and Bacon, K.J. (2014). Organizational structure and operation of the Illinois wine industry. Agricultural and Resource Economics Review, 43(1), 104-124.

Furubotn, E.G. and Richter, R. (1998). Institutions and Economic Theory: The Contribution of the New Institutional Economics, Ann Arbor: The University of Michigan Press.

Goodhue, R.E., Heien, D.M., Lee, H., and Sumner, D.A. (2003). Contracts and quality in the California winegrape industry. Review of Industrial Organization, 23(3), 267-282.

Insel, B. (2008). The U.S. wine industry. Business Economics, 43(1), 68-73.

Jensen, M.C., and Meckling, W.H. (1976). Theory of the firm: Managerial behavior, agency costs and ownership structure. Journal of Financial Economics, 3(4), 305-360.

Kahan, M., and Yermack, D. (1998). Investment Opportunities and the Design of Debt Securities. Journal of Law, Economics and Organization, 14(1), 136-151.

Macaulay, S. (1963). Non-contractual relations in business: A preliminary study. American Sociological Review, 28(1), 55-67.

Masten, S.E., and Saussier, S. (2002). Econometrics of contracts: An assessment of developments in the empirical literature on contracting. In Brousseau, E., and Glachant, J.-M. (Eds.). The Economics of Contracts. Cambridge: Cambridge University Press, 273-292.

Mayer, K.J., and Argyres, N.S. (2004). Learning to contract: Evidence from the personal computer industry. Organization Science, 15(4), 394-410.

Milgrom, P. and Roberts, J. (1992). Economics, Organization and Management, London: Prentice- Hall.

Poppo, L., and Zenger, T. (2002). Do formal contracts and relational governance function as substitutes or complements? Strategic Management Journal, 23(8), 707-725.

Poppo, L., and Zhou, K.Z. (2014). Managing contracts for fairness in buyer-supplier exchanges. Strategic Management Journal, 35(10), 1508-1527.

Riekhof, G.M., and Sykuta, M.E. (2005). Politics, economics, and the regulation of direct interstate shipping in the wine industry. American Journal of Agricultural Economics 87(2), 439-452.

Ryall, M.D., and Sampson, R.C. (2009). Formal contracts in the presence of relational enforcement mechanisms: Evidence from technology development projects. Management Science, 55(6), 906-925.

Scott, R.E. (2006). The law and economics of incomplete contracts. Annual Review of Law and Social Science, 2, 279-297.

Storchmann, K. (2012). Wine economics. Journal of Wine Economics, 7(1), 1-33.

Sun, L., Gómez, M.I., Chaddad, F.R., and Ross, R.B. (2014). Distribution channel choices of wineries in emerging cool climate regions. Agricultural and Resource Economics Review, 43 (1), 87-103.

Sykuta, M.E. (2008). New institutional econometrics: The case of research on contracting and organization. In Brousseau, E., and Glachant, J.-M. (Eds.). New Institutional Economics: A Guidebook. Cambridge: Cambridge University Press, 122-141.

Sykuta, M.E. (2012). The nature of the deal in the post-crisis financial market. Entrepreneurial Business Law Journal, 7(1), 27-44.

Thach, E.C., and Olsen, J. (2006). Building strategic partnerships in wine marketing: Implications for wine distribution. Journal of Food Products Marketing, 12(3), 71-86.

Thornton, J.A. (2013). American Wine Economics: An Exploration of the U.S. Wine Industry. Los Angeles: University of California Press.

Williamson, O.E. (1979). Transaction-Cost Economics: The Governance of Contractual Relations. Journal of Law and Economics, 22(2), 233-261.

Williamson, O.E. (1985). The Economic Institutions of Capitalism: Firms, Markets and Relational Contracting. New York: Free Press. 
Williamson, O.E. (1996). The Mechanisms of Governance. New York: Oxford University Press. Wines \& Vines 2007 Directory \& Buyers Guide. (2007). San Rafael, CA: Wine Communications Group.

Zylbersztajn, D., and Miele, M. (2005). Stability of contracts in the Brazilian wine industry. Revista de Economia e Sociologia Rural, 43(2), 353-371. 